\title{
ANALISIS FAKTOR YANG MEMPENGARUHI PRODUKSI KELAPA DALAM (Cocos nucifera Linn) PADA LAHAN GAMBUT DAN LAHAN MINERAL DI KABUPATEN INDRAGIRI HILIR PROVINSI RIAU
}

\section{Analysis Factors Affecting Production of Coconut (Cocos nucifera Linn) on Peatlands and Mineral Land in Indragiri Hilir District, Riau Province}

\author{
Khairizal, Sisca Vaulina dan Hajry Arief Wahyudy \\ Fakultas Pertanian Universitas Islam Riau. Jl. Kaharuddin Nasution 113, Pekanbaru 28284 Riau \\ Telp. : 0761-72126 ext. 123, Fax : 0761-674681 \\ [Diterima: November 2018; Disetujui: Desember 2018]
}

\begin{abstract}
In Indragiri Hilir Regency, coconut grows on peat land and mineral land. The difference in land conditions will affect the amount of production and income that farmers will receive. The objectives of this study are: (1) To determine the characteristics of Deep Coconut farmers on peat land and mineral land in Indragiri Hilir Regency. (2) Analyzing the production and income of Deep Coconut farmers on peat land and mineral land in Indragiri Hilir Regency. (3) Analyzing what factors influence the production of Deep Coconut on peat land and mineral land in Indragiri Hilir Regency. This study uses a survey method. The research location was determined in Kempas District for peat land and Concong District for mineral land. The sample is determined by purposive sampling, which is based on the age of coconut plants with a range of 10-15 years. Data were analyzed descriptively qualitatively and quantitatively, using the Cobb-Douglas production function. The results of the study show that (1) peat land and mineral land farmers have relatively the same characteristics farmers, the age of productive farmers, average education level graduating from elementary school, number of family dependents 3-4 people and having experience in farming for 20-29 years. (2) Coconut production on peat land is greater than mineral land, as well as income. (3) Factors that significantly affect coconut production on peat land are land and the number of productive plants, while for mineral land, they are processed.
\end{abstract}

Keywords: Coconut, Peat Land, Mineral land, Cobb-Douglas

\begin{abstract}
ABSTRAK
Di Kabupaten Indragiri Hilir, kelapa tumbuh pada lahan gambut dan lahan mineral. Perbedaan keadaan lahan akan berpengaruh pada jumlah produksi dan pendapatan yang akan diterima petani. Tujuan penelitian ini yaitu: (1) Mengetahui karakteristik petani Kelapa Dalam pada lahan gambut dan lahan mineral di Kabupaten Indragiri Hilir. (2) Menganalisis produksi dan pendapatan petani Kelapa Dalam pada lahan gambut dan lahan mineral di Kabupaten Indragiri Hilir. (3) Menganalisis faktor apa saja yang mempengaruhi produksi Kelapa Dalam pada lahan gambut dan lahan mineral di Kabupaten Indragiri Hilir. Penelitian ini menggunakan metode survey. Lokasi penelitian ditetapkan di Kecamatan Kempas untuk lahan gambut dan Kecamatan Concong untuk lahan mineral. Sampel pada ditentukan secara purposive sampling, yang didasarkan pada umur tanaman kelapa dengan kisaran 10-15 tahun. Data dianalisis secara deskriptif kualitatif dan kuantitatif, menggunakan fungsi produksi Cobb-Douglas. Hasil penelitian menunjukkan bahwa (1) Petani lahan gambut dan lahan mineral memiliki karakteirstik petani yang relatif sama, umur petani produktif, tingkat pendidikan rata-rata tamat $\mathrm{SD}$, jumlah tanggungan keluarga 3-4 orang dan memiliki pengalaman berusahatani selama 20-29 tahun. (2) Produksi kelapa pada lahan gambut lebih besar dibandingkan dengan lahan mineral, begitu pula dengan pendapatan. (3) Faktor yang signifikan mempengaruhi produksi kelapa di lahan gambut adalah lahan dan jumlah tanaman produktif, sedangkan untuk lahan mineral yakni terusi.
\end{abstract}

Kata Kunci: Kelapa, Lahan Gambut, Lahan Mineral,Cobb-Douglas. 


\section{PENDAHULUAN}

Indragiri Hilir sebagai kabupaten penghasil kelapa dalam terbesar di Propinsi Riau, menyebabkan wilayah ini diberi slogan "hamparan kelapa dunia". Produksi kelapa dalam di kabupaten Indragiri Hilir mencapai 299.634 ton/tahun dengan luas lahan 392.461 hektar, BPS Inhil (2016). Di kabupaten ini, kelapa dapat tumbuh di setiap kecamatan. Kelapa tumbuh pada lahan gambut dan lahan mineral.

Perbedaan keadaan lahan tentunya akan berpengaruh pada jumlah produksi dan pendapatan yang akan diterima petani. Dengan berusahatani tanaman kelapa dalam jumlah yang lebih banyak serta melakukan perawatan yang benar, penghasilan yang kecil pasti akan meningkat.

Vaulina, dkk (2017) permasalahan Kelapa Dalam di Kabupaten Indragiri Hilir dari segi pengusahaannya dalam bentuk perkebunan rakyat yang bercirikan : (1) hasil usahatani masih bersifat tradisional yaitu berbentuk kelapa butiran, (2) produktivitas rendah yang salah satu penyebabnya banyak tanaman tua dan rusak, dan (3) belum menggunakan bibit unggul. Sebagian petani memiliki lahan usahatani yang sempit dan jarak tanam yang tidak teratur serta belum dilaksanakannya penerapan teknologi anjuran berupa penggunaan pupuk di dalam pengembangan usahataninya, sehingga sangat sukar diharapkan perolehan produksi dan pendapatan yang optimal.

Tujuan penelitian ini adalah untuk mengetahui: (1) karakteristik petani Kelapa Dalam pada lahan gambut dan lahan mineral di Kabupaten Indragiri Hilir, (2) produksi dan pendapatan petani Kelapa Dalam pada lahan gambut dan lahan mineral di Kabupaten Indragiri Hilir, (3) Faktor-faktor yang mempengaruhi produksi Kelapa Dalam pada lahan gambut dan lahan mineral di Kabupaten Indragiri Hilir?

\section{METODE PENELITIAN}

Penelitian ini menggunakan metode survei. Penelitian ini dilaksanakan di dua kecamatan yang ada di kabupaten Indragiri Hilir, yakni Kecamatan Kempas untuk lahan gambut dan Kecamatan Concong untuk lahan mineral. Sampel pada penelitian ini ditentukan secara purposive sampling, yang didasarkan pada umur tanaman kelapa dengan kisaran 1015 tahun. Kategori umur diambil sebagai sampel dengan pertimbangan bahwa umur tanaman kelapa menentukan tingkat produksi tanaman kelapa. Penentuan umur tanaman karena pada umur tersebut tanaman kelapa telah berproduksi maksimal. Untuk Kecamatan Kempas, jumlah sampel 25 orang, dan Kecamatan Concong dengan jumlah 19 orang. Dengan demikian, jumlah sampel 44 orang. Perbedaan jumlah sampel dikarenakan, umumnya petani kelapa memiliki umur kelapa di atas 15 tahun.

\section{Analisis Data \\ Analisis Deskriptif}

Untuk menganalisis karakteristik petani kelapa dalam di Kabupaten Indragiri Hilir digunakan analisis deskriptif dan disajikan dalam bentuk tabel. Unit analisis pada karakteristik petani yakni; umur petani, pendidikan, jumlah tanggungan keluarga dan pengalaman berusahatani kelapa.

\section{Produksi dan Pendapatan Petani Kelapa Dalam}

Setelah karakteristik petani di analisis dengan analisis deskriptif, dilanjutkan dengan mengacu pada rumus perhitungan biaya, pendapatan, dan penerimaan. Untuk mengetahui besarnya biaya yang dikeluarkan, digunakan perhitungan:

$\mathrm{TC}=\mathrm{FC}+\mathrm{VC}$

Dimana: $\quad \mathrm{TC}=$ Total Cost (Biaya Total)

$\mathrm{FC}=$ Fixed Cost (Biaya Tetap)

$\mathrm{VC}=$ Variabel Cost (Biaya Variabel $)$

Menurut Soekartawi (2003), pendapatan usahatani adalah selisih antara jumlah penerimaan dan semua biaya.

$\mathrm{Pd}=\mathrm{TR}-\mathrm{TC}$

Dimana: $\mathrm{Pd}=$ Pendapatan Usaha Tani Kelapa

$\mathrm{TR}=$ Total Penerimaan

$\mathrm{TC}=$ Total Biaya

Sedangkan untuk menghitung penerimaan usahatani adalah produksi yang diperoleh dengan harga jual.

$\mathrm{TR}=\mathrm{Q} \times \mathrm{Pq}$ 
$\mathrm{Q}=$ Jumlah produksi yang dijual

$\mathrm{Pq}=$ Harga kelapa per butir

Peralatan yang digunakan pada usahatani kelapa dalam umumnya tidak habis dipakai untuk satu kali periode produksi (lebih dari satu tahun). Oleh karena itu, biaya peralatan yang dihitung sebagai komponen biaya produksi adalah nilai penyusutannya. Untuk menghitung besarnya biaya penyusutan alat yang digunakan yakni metode garis lurus (straight line method) yang dikemukakan oleh Rahim (2008), dengan rumus:

$\mathrm{D}=\frac{\mathrm{C}-\mathrm{SV}}{\mathrm{UL}}$

Keterangan:

D : Biaya penyusutan (Rp/unit/tahun)

C : Harga beli (Rp/unit/tahun)

SV : Nilai sisa $20 \%$ dari harga beli (Rp/unit/tahun)

UL : Masa pakai alat (tahun)

\section{Fungsi Produksi Cobb-Douglas}

Untuk menganalisis faktor-faktor yang mempengaruhi produksi kelapa dalam digunakan fungsi produksi Cobb-Douglas. Fungsi Cobb-Douglas dalam penelitian ini digunakan untuk mengetahui faktor-faktor yang mempengaruhi produksi kelapa dalam. Model ini dipilih berdasarkan pertimbangan bahwa; (1) Model fungsi Cobb-Douglas adalah model yang lazim digunakan dalam penelitian ekonomi pertanian karena sifatnya yang praktis dan mudah ditrasformasikan ke dalam bentuk linear (Soekartawi, 2003); (2) Menurut Gujarati (2001) koefisien regresi yang ditunjukkan oleh fungsi produksi Cobb-Douglas merupakan elastisitas faktor produksi dan memberikan informasi mengenai pengaruh skala terhadap hasil (return to scale).

Pada dasarnya fungsi tersebut berasal dari regresi yang persamaan umumnya dapat ditulis sebagai berikut:

$\mathrm{Y}=\mathrm{a}+\mathrm{bX}$

Dimana:

$\mathrm{Y}=$ variabel yang dipengaruhi (variabel terikat)

$\mathrm{X}=$ variabel yang mempengaruhi (variabel bebas)

Sedangkan fungsi produksi CobbDouglas secara matematis dapat ditulis sebagai berikut:

$$
Y_{i}=\beta \beta_{0} X_{1}^{\beta 2} X_{2}^{\beta 3} e_{1}^{u i}
$$

Persamaan (6) diatas, dikenal dengan model regresi exponensial dengan bentuk persamaannya dapat ditulis sebagai berikut:

$$
\mathrm{Y}_{\mathrm{i}}=\beta_{0} \beta_{1} \mathrm{X}_{1}^{\beta 1} \mathrm{e}^{\mathrm{ui}} \text {. }
$$

Dimana:

$$
\begin{array}{ll}
\mathrm{Y} & =\text { Output } \\
\mathrm{X} 2 & =\text { Labour input } \\
\mathrm{X} 3 & =\text { Capital input } \\
\mathrm{u} & =\text { Stochastic disturbance term }
\end{array}
$$

$\beta 1, \beta 2, \beta 3=$ Parameters

$\mathrm{i} \quad=1,2,3$

Dengan ketentuan, bahwa apabila thitung lebih besar dari pada t-tabel, maka variabel yang bersangkutan berpengaruh nyata atau sangat nyata terhadap Y (output) dan apabila t-hitung lebih kecil dibandingkan dengan $\mathrm{t}$-tabel, maka varibel yang bersangkutan tidak berpengaruh nyata terhadap Y. Akan tetapi pada persamaan (7) terlihat bahwa hubungan antara output dan input yang terlibat dalam proses produksi tidak linier, sehingga sulit dianalisis. Oleh karena itu harus dilinierkan terlebih dahulu dengan mentransformasikan dalam bentuk logaritma natural (ln atau $\log$ ) sebagai berikut:

$\ln Y \mathrm{i}=\ln \beta_{1}+\beta_{2} \ln \mathrm{X}_{2 \mathrm{i}}+\beta_{3} \ln \mathrm{X}_{3 \mathrm{i}}+$ ui $=\ln \beta_{0}-\beta_{2} \ln X_{2 \mathrm{i}}+\beta_{3} \ln X_{3 \mathrm{i}}+$ ui

Dimana $\beta_{0}=\ln \beta_{1}$

Persamaan (8) merupakan ekspresi dari persamaan (7) yakni:

$\ln \mathrm{Yi}=\ln \beta_{1}+\beta_{2} \ln \mathrm{X}_{\mathrm{i}}+\mathrm{u} \mathrm{i}$

Persamaan (9) dapat pula ditulis dalam bentuk model:

$\ln \mathrm{Yi}=\beta+\beta_{2} \ln \mathrm{X}_{\mathrm{i}}+\mathrm{ui}$ dimana $\beta=\ln \beta_{1}$

Oleh karena $\beta=\ln \beta_{1}$, maka persamaan (9) dapat ditulis menjadi persamaan (10). Model ini adalah linier terhadap parameter $\beta_{1}$ dan $\beta_{2}$, linier terhadap variabel Y maupun X. Model ini disebut juga dengan log-log model, double log model, atau model log-linier yang dapat diestimasi dengan regresi OLS (Gujarati, 2001).

Untuk menentukan faktor yang berpengaruh terhadap produksi kelapa dalam digunakan analisis kuantitatif melalui pendungaan Ordinary Least Square (OLS). Analisis ini dilakukan melalui pendekatan fungsi produksi bertipe Cobb-Douglas yaitu suatu 
fungsi atau persamaan yang melibatkan dua variabel atau lebih, variabel yang satu disebut variabel independent $(\mathrm{Y})$ dan yang lain disebut variable dependent (X) yang secara matematis formulasinya dapat dituliskan sebagai berikut:

$$
\mathrm{Y}=\mathrm{a} \mathrm{X}_{1}^{\mathrm{b} 1} \mathrm{X}_{2}^{\mathrm{b} 2} \mathrm{X}_{3}^{\mathrm{b} 3} \mathrm{X}_{4}^{\mathrm{b} 4}+\mathrm{e}^{\mathrm{u}}
$$

Agar fungsi produksi Cobb-Douglas dapat diestimasi dengan metode OLS maka diubah ke dalam bentuk logaritma natural sebagai berikut:

$\operatorname{Ln} \mathrm{Y}=\mathrm{Ln} a+\mathrm{b}_{1} \operatorname{Ln} \mathrm{X}_{1}+\mathrm{b}_{2} \operatorname{Ln} \mathrm{X}_{2}+\mathrm{b}_{3} \operatorname{Ln} \mathrm{X}_{3}+\mathrm{b}_{4} \operatorname{Ln} \mathrm{X}_{4}+\mathrm{u} \ldots$... (12)

Dimana:

$\mathrm{Y}=$ Produksi kelapa dalam (Butir)

$\mathrm{X}_{1}=$ Luas lahan (hektar)

$\mathrm{X}_{2}=$ Jumlah tanaman produktif (batang)

$\mathrm{X}_{3}=$ Tenaga kerja $(\mathrm{HOK})$

$\mathrm{X}_{4}=$ Terusi $(\mathrm{Kg})$

Dengan asumsi bahwa, E (ui) $=0$, maka ei $=\mathrm{Y}$ (yang diduga) $-\mathrm{Y}$ (penduga)

\section{Pengujian Hipotesis secara Parsial (Uji t)}

Pengujian secara parsial menggunakan uji t yang merupakan uji pengaruh signifikan variabel independen terhadap variabel dependen secara individual. Uji signifikansi adalah prosedur di mana hasil sampel digunakan untuk menentukan keputusan untuk menerima atau menolak Ho berdasarkan nilai uji statistik yangdiperoleh dari data. Widarjono (2007), prosedur dari uji t sebagai berikut:

1) Membuat hipotesa nol (Ho) dan hipotesa alternatif (Ha)

2) Menghitung $t$ dengan rumus:

$\mathrm{t}_{\text {hitung }}=\frac{\mathrm{b}_{\mathrm{i}} \mathrm{-b}}{\mathrm{S}_{\mathrm{b}}}$

Dimana: bi $=$ Koefisien bebas ke- $i$

$\mathrm{b}=$ Nilai hipotesis nol

$\mathrm{Sb}=$ Simpangan baku (standar deviasi) dari variabel bebas ke- $i$

3) Mencari nilai kritis $t$ dari tabel $t$ dengan $d f=$ $\mathrm{n}-\mathrm{k}$ dan $\alpha$ yang tertentu

4) Keputusan untuk menerima atau menolak Ho didasarkan pada perbandingan $\mathrm{t}$ hitung dan $\mathrm{t}$ tabel (nilai kritis). Jika: $\mathrm{t}$ hitung $>\mathrm{t}$ tabel, maka Ho ditolak dan Hi diterima $\mathrm{t}$ hitung $<\mathrm{t}$ tabel, maka Ho diterima dan Hi ditolak.

\section{Pengujian Hipotesis secara Serempak (Uji}

F)

Pengujian secara serempak menggunakan uji $F$. Uji $F$ bertujuan untuk menguji pengaruh semua variabel independen terhadap variabel dependen secara bersamasama. Prosedur pengujian uji $\mathrm{F}$ adalah sebagai berikut:

1) Membuat hipotesa nol (Ho) dan hipotesa alternatif (Ha)

2) Menghitung nilai F.hitung dengan rumus:

$\mathrm{F}=\frac{\mathrm{R}^{2} /(\mathrm{k}-1)}{\left(1-\mathrm{R}^{2}\right) /(\mathrm{n}-\mathrm{k})}$

Dimana: $\mathrm{R}^{2}=$ Koefisien determinasi

$\mathrm{k}=$ Jumlah variabel independen

$\mathrm{n}=$ Jumlah sampel

3) Mencari nilai kritis (F tabel); df (k-1, n-k). Dimana: $\mathrm{k}=$ jumlah parameter termasuk intersep.

4) Keputusan untuk menerima atau menolak Ho didasarkan pada perbandingan $\mathrm{F}$ hitung dan $\mathrm{F}$ tabel. Jika: $\mathrm{F}$ hitung $>\mathrm{F}$ tabel, maka Ho ditolak dan Hi diterima $\mathrm{F}$ hitung $<\mathrm{F}$ tabel, maka Ho diterima dan Hi ditolak.

\section{Koefisien Determinasi $\left(\mathbf{R}^{2}\right)$}

Menurut Gujarati (2001) koefisien determinasi adalah untuk mengetahui seberapa besar persentase sumbangan variabel bebas terhadap variabel terikat yang dapat dinyatakan dalam persentase. Besarnya persentase pengaruh semua variabel bebas terhadap nilai variabel terikat dapat diketahui dari besarnya koefisien determinasi $\left(\mathrm{R}^{2}\right)$. Besarnya koefisien determinasi berkisar antara nol sampai dengan satu. Semakin mendekati nol besarnya koefisien determinasi suatu persamaan regresi, maka semakin kecil pengaruh semua variabel bebas terhadap variabel terikat. Sebaliknya, Semakin mendekati satu besarnya koefisien determinsi suatu persamaan regresi, maka semakin besar pengaruh semua variabel bebas terhadap variabel terikat.

\section{HASIL DAN PEMBAHASAN}

\section{Karakteristik Petani Kelapa Dalam pada Lahan Gambut dan Lahan Mineral}

Karakterisik petani kelapa dalam yang dibahas pada penelitian ini meliputi: umur; pendidikan; jumlah tanggungan keluarga; dan pengalaman berusahatani. Umur dapat melihat kemampuan fisik dari petani kelapa dalam untuk mengusahakan usahatani kelapa; pendidikan menentukan pengetahuan dan keterampilan petani kelapa dalam; jumlah 
tanggungan keluarga berkaitan erat dengan usaha petani untuk meningkatkan pendapatan dalam memenuhi kebutuhan keluarga; pengalaman berusahatani akan memberikan kebijakan dan keputusan yang akan diambil dalam berusaha. Keempat hal tersebut tercantum pada Tabel 1.

\section{Umur}

Berdasarkan Tabel 1, petani sampel mempunyai tingkat umur yang berbeda-beda, petani kelapa memiliki umur berkisar antara 2564 tahun dengan rata-rata umur 39,74 tahun untuk lahan gambut dan 43,37 tahun untuk lahan mineral. Umur petani kelapa pada lahan gambut paling banyak berkisar antara 33-40 tahun sebanyak 10 orang $(40,00 \%)$ dan pada lahan mineral berkisar antara 41-48 tahun $(52,63 \%)$. Sementara itu, umur 57-64 tahun merupakan kelompok umur petani kelapa yang masih terdapat di lahan gambut sebanyak 4 orang $(16,00 \%)$. Hasil penelitian di lapangan menunjukkan bahwa masih terdapat beberapa petani yang berumur $>60$ tahun, secara fisik mereka masih mampu melaksanakan tugastugas sebagai petani kelapa. Pada umumnya usahatani ini sudah dilaksanakan sejak masih usia muda. Kelapa tidak memerlukan perawatan yang intensif, cukup hanya menunggu berbuah saja dengan sekali-sekali membersihkan rumput disekitar pohon kelapa.

Mayoritas petani kelapa berada di bawah umur 60 tahun, yang berarti bahwa petani kelapa tergolong pada usia produktif. Hal ini sangat potensial dalam upaya pengembangan usahatani kelapa, sebab pada usia tersebut mempunyai daya fisik dan daya fikir yang lebih baik. Selain itu, mampu menerima teknologi baru dibidang pertanian seperti penggunaan pupuk, pestisida dan bibit unggul kelapa.

\section{Pendidikan}

Berdasarkan Tabel 1, petani lahan gambut dan lahan mineral mayoritas berpendidikan tamat Sekolah Dasar (SD), masing-masing dengan jumlah 13 orang $(52,00 \%)$ dan 11 orang $(57,89 \%)$. Di daerah sampel penelitian, petani kelapa belum ada yang menempuh pendidikan tingkat perguruan tinggi. Faktor rendahnya tingkat pendidikan petani kelapa selain karena faktor biaya yang tidak ada, juga karena petani kelapa umumnya tinggal di dekat kebun kelapa, sehingga akses untuk ke kota agak jauh. Selain itu tanaman kelapa sudah ada dari orang tua mereka, sehingga anak-anak mereka tinggal meneruskan usahatani kelapa tanpa harus sekolah terlalu tinggi (cukup mengerti baca dan tulis saja).

Hasil penelitian Lamusa (2005), menunjukkan bahwa pendidikan responden (petani kelapa) terdiri atas SD tamat $71,43 \%$, SLTP $11,43 \%$, dan SLTA $17,14 \%$. Dengan demikian, kualitas sumberdaya petani kelapa dalam ditinjau dari aspek pendidikan secara umum relatif cukup baik. Kondisi demikian mencerminkan bahwa motivasi petani relatif cukup/tidak tinggi dalam melaksanakan kegiatan usahataninya terutama dalam

Tabel 1. Karakteristik Petani Kelapa pada Lahan Gambut dan Lahan Mineral di Kabupaten Indragiri Hilir, Tahun 2018

\begin{tabular}{|c|c|c|c|c|c|}
\hline \multirow[t]{2}{*}{ No } & \multirow[t]{2}{*}{ Karakteristik } & \multicolumn{2}{|c|}{ Lahan Gambut } & \multicolumn{2}{|c|}{ Lahan Mineral } \\
\hline & & $\begin{array}{c}\text { Jumlah Petani } \\
\text { (Jiwa) }\end{array}$ & $\begin{array}{c}\text { Persentase } \\
(\%)\end{array}$ & $\begin{array}{c}\text { Jumlah Petani } \\
\text { (Jiwa) }\end{array}$ & $\begin{array}{c}\text { Persentase } \\
(\%)\end{array}$ \\
\hline \multicolumn{6}{|c|}{ Umur } \\
\hline 1 & $25-32$ & 7 & 28,00 & 2 & 10,53 \\
\hline 2 & $33-40$ & 10 & 40,00 & 5 & 26,31 \\
\hline 3 & $41-48$ & 2 & 8,00 & 10 & 52,63 \\
\hline 4 & $49-56$ & 2 & 8,00 & 2 & 10,53 \\
\hline 5 & $57-64$ & 4 & 16,00 & - & - \\
\hline \multicolumn{6}{|c|}{ Pendidikan } \\
\hline 1 & SD & 13 & 52,00 & 11 & 57,89 \\
\hline 2 & SMP & 5 & 20,00 & 5 & 26,32 \\
\hline 3 & SLTA & 7 & 28,00 & 3 & 15,79 \\
\hline \multicolumn{6}{|c|}{ Jumlah Tanggungan Keluarga } \\
\hline 1 & $1-2$ & 5 & 20,00 & 3 & 15,79 \\
\hline 2 & $3-4$ & 13 & 52,00 & 15 & 78,95 \\
\hline 3 & $5-6$ & 6 & 24,00 & 1 & 5,26 \\
\hline 4 & $7-8$ & 1 & 4,00 & - & - \\
\hline \multicolumn{6}{|c|}{ Pengalaman Berusahatani } \\
\hline 1 & $<10$ & 3 & 12,00 & - & - \\
\hline 2 & $10-19$ & 9 & 36,00 & 6 & 31,57 \\
\hline 3 & $20-29$ & 11 & 44,00 & 8 & 42,11 \\
\hline 4 & $30-39$ & 2 & 8,00 & 5 & 26,32 \\
\hline
\end{tabular}


menanggulangi risiko usahatani yang akan terjadi. Kenyataan di lapangan membuktikan bahwa petani jarang melakukan peremajaan kelapa dalam meskipun sudah berusia hampir tiga per empat abad (66,70 tahun), sehingga produktivitasnya rata-rata cenderung menurun.

\section{Jumlah Anggota Keluarga}

Berdasarkan Tabel 1, jumlah anggota keluarga petani kelapa baik pada lahan gambut dan lahan mineral, dengan jumlah tanggungan sebanyak 3-4 orang masing-masing berjumlah 13 orang $(52,00 \%)$ untuk lahan gambut dan 15 orang $(78,95 \%)$ untuk lahan mineral. Dilihat dari jumlah tanggungan keluarga petani kelapa dapat dikategorikan memiliki jumlah tanggungan yang banyak. Sebagian besar petani sampel memiliki tanggungan keluarga di luar keluarga inti (ayah, ibu dan anak); yakni saudara dekat; hingga anak mereka yang telah menikah. Ini diharapkan dapat mengelola kelapa di kebun milik mereka (kebun kelapa yang telah diwariskan) secara bersama-sama. Jumlah tanggungan keluarga mempengaruhi penghasilan dalam suatu usahatani. Jumlah keluarga yang besar merupakan bantuan tenaga kerja yang dapat mengelola usahatani kelapa. Dengan adanya jumlah tanggungan petani yang memiliki tanggungan lebih dari 3 orang, maka dapat memperkecil penggunaan tenaga kerja dari luar keluarga dan sangat mempengaruhi pendapatan petani.

\section{Pengalaman Berusahatani}

Lama berusahatani petani kelapa mempengaruhi perilakunya dalam mengelola usahataninya. Bagi petani yang memiliki pengalaman berusahatani lebih lama atau banyak, cenderung memiliki banyak pengetahuan berusahatani, sehingga mereka lebih berhati-hati untuk mengambil keputusan. Berdasarkan Tabel 1, pengalaman berusahatani petani kelapa umumnya dengan pengalaman 2029 tahun dengan masing-masing persentase pada lahan gambut $44,00 \%$ (11 orang) dan lahan mineral $42,11 \%$ (8 orang). Sementara itu, pengalaman berusahatani yang paling kecil yakni $<10$ tahun persentase $12,00 \%$ (3 orang) terdapat di lahan gambut. Apabila dirataratakan, maka pengalaman berusahatani petani sampel di kabupaten Indragiri Hilir, pada lahan gambut 18,80 tahun dan lahan mineral 21,32 tahun. Hal ini mengandung arti bahwa jika petani kelapa membudidayakan kelapa dari tahapan kegiatan pembukaan lahan dan penanaman bibit kelapa, maka tanaman kelapa masih dalam masa produksi.

Produksi dan Pendapatan Petani Kelapa Dalam pada Lahan Gambut dan Lahan Mineral di Kabupaten Indragiri Hilir

Petani sampel di Kecamatan Kempas

(Lahan Gambut) menanam tanaman kelapa dengan jarak tanam $7,10 \mathrm{~m} \times 6,25 \mathrm{~m}$, dengan sistem penanaman menggunakan sistem lurus dan jumlah pohon 225 pohon/hektar. Sementara, untuk di Kecamatan Concong (Lahan Mineral) jarak tanam kelapa 7,10 m x $7,10 \mathrm{~m}$ dengan jumlah tanaman 198 pohon/hektar. Hal ini belum sesuai dengan anjuran dari Direktorat Jendral Perkebunan (2014), bahwa jarak tanam kelapa antara $9 \mathrm{mx} 9 \mathrm{~m}$ atau $8,5 \mathrm{mx} 8,5 \mathrm{~m}$ dengan jumlah tanaman kelapa 123 pohon/hektar. Namun, penelitian sejenis di Desa Tolombukan (Ruauw dkk, 2011), petani kelapa di tempat penelitian sudah sesuai dengan anjuran Dirjenbun yakni menanam tanaman kelapa dengan jarak tanam 10x10 meter. Dengan sistem penanaman yang dilakukan bervariasi, tapi umumnya menggunakan sistem persegi atau lurus dengan jumlah pohon 100-110 pohon per hektar.

Memanen kelapa menggunakan pengait kelapa. Pengait kelapa ini berupa alat seperti sabit yang disambungkan dengan bambu panjang. Periode panen kelapa dalam satu tahun pemetikan dilakukan minimal 4 kali (tiap tiga bulan) atau maksimal 6 kali (tiap 2 bulan). Kriteria buah siap panen adalah sebagai berikut: (1) buah kelapa umumnya siap matang panen umurnya 11-13 bulan; (2) warna kulit buah kecoklat-coklatan (umumnya) atau hijau; (3) apabila buah diguncang air kelapanya berbunyi nyaring. Berdasarkan hasil penelitian pada lahan gambut dan lahan mineral, dengan umur tanaman kelapa pada masa produktif (15-25 tahun) memiliki perbedaan produktifitas. Secara rinci dapat dilihat Gambar 1. 


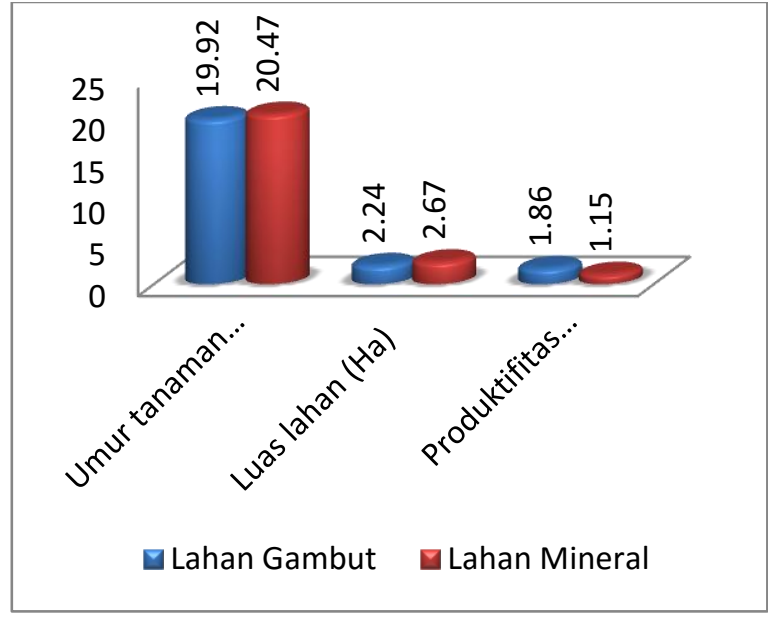

Gambar 1. Umur Tanaman, Luas lahan dan Produktifitas Kelapa Dalam pada Lahan Gambut dan Lahan Mineral di Kabupaten Indragiri Hilir, Tahun 2018

Berdasarkan Gambar 1, diperoleh informasi bahwa perbedaan jenis lahan menentukan perbedaan produktifitas, 1,86 butir/ha untuk lahan gambut dan 1,15 butir/ha untuk lahan mineral. Umur tanaman sampel rata-rata 19,92 tahun untuk lahan gambut dan 20,47 tahun untuk lahan mineral. Apabila dilihat dari luas lahan, maka lahan mineral memiliki luas lahan lebih besar jika dibandingkan lahan gambut. Perbedaan ini disebabkan karena di lahan mineral, petani masih konsisten untuk menanam kelapa sedangkan di lahan gambut sebagian petani ada yang mengalihgunakan lahan ke tanaman lain, salah satunya adalah kelapa sawit.

Produksi kelapa yang dijadikan objek dalam penelitian ini adalah kelapa dalam bentuk butiran. Berdasarkan hasil penelitian, luas lahan rata-rata petani kelapa pada lahan gambut adalah 2,24 ha dan pada lahan mineral 2,67 hektar, dengan rata-rata produksi per panen $4.008,44 \mathrm{~kg} /$ panen pada lahan gambut dan $2.887,89 \mathrm{~kg} /$ panen pada lahan mineral. Secara rinci dapat dilihat pada Tabel 2 .
Berdasarkan Tabel 2, pendapatan kotor yang diterima petani Kelapa Dalam sebesar Rp 5.003.728,00/panen dan pendapatan bersih $\mathrm{Rp}$ 1.237.697,05/panen atau $\mathrm{Rp} 412.565,68 /$ bulan pada lahan gambut. Pada lahan mineral, pendapatan kotor yang diterima petani $2.887 .894,74 \mathrm{~kg} /$ panen dan pendapatan bersih $\mathrm{Rp} 386.329,06 \mathrm{~kg} /$ panen atau $\mathrm{Rp} 128.776,35$ $\mathrm{kg} /$ panen. Rendahnya pendapatan yang diterima petani karena harga kelapa yang berfluktuasi. Pada saat penelitian, harga kelapa sedang murah.

Hasil penelitian Pangkey, dkk (2016), pendapatan usahatani kelapa di Kecamatan Sinonsayang berkisar antara Rp 3.200.00/bulan - Rp 4.106.000/bulan. Dapat disimpulkan bahwa pendapatan petani Kelapa Dalam di Kabupaten Indragiri Hilir tergolong rendah. Supadi dan Nurmanaf (2006), rendahnya penghasilan yang diperoleh dari kelapa menyebabkan petani tidak memiliki modal untuk memelihara kebun secara intensif, apalagi menggarap lahan perkebunan secara optimal maupun mengolah hasil. Meskipun begitu, Dongoran (2013), usahatani kelapa memiliki peluang ekonomi yang sangat baik untuk dikembangkan dalam upaya peningkatan ekonomi kerakyatan.

Dari sisi pendapatan usahatani belum mampu menunjang kehidupan keluarga petani secara layak. Hasil studi yang dilaksanakan disentra-sentra produksi kelapa di Indonesia menunjukkan bahwa kehidupan keluarga petani kelapa secara umum sampai saat ini masih berada dibawah garis kemiskinan (Tarigans, 2002). Bavappa et al. (1995) melaporkan bahwa proporsi pendapatan petani kelapa di Indonesia sangat kecil hanya $20 \%$ dari total pendapatannya. Disamping itu, usaha-usaha yang telah dilaksanakan pemerintah dalam periode tiga dekade terakhir belum sepenuhnya memberikan perbaikan taraf hidup petani kelapa. Tarigans, (2005), kenyataan demikian, menunjukkan peranan ekonomi komoditas

Tabel 2. Pendapatan Petani Kelapa Dalam pada Lahan Gambut dan Lahan Mineral di Kabupaten Indragiri Hilir, Tahun 2018

\begin{tabular}{clrr}
\hline No & \multicolumn{1}{c}{ Uraian } & Lahan Gambut & \multicolumn{1}{c}{ Lahan Mineral } \\
\hline 1 & Produksi (Kg) & $4.008,44$ & $2.887,89$ \\
2 & Harga (Rp/Kg) & $1.240,00$ & $1.000,00$ \\
3 & Pendapatan Kotor (Rp/panen) & $5.033 .728,00$ & $2.887 .894,74$ \\
4 & Pendapatan Bersih (Rp/panen) & $1.237 .697,05$ & $386.329,06$ \\
\hline
\end{tabular}


Tabel 3. Uji F Kelapa Dalam Pada Lahan Gambut dan Lahan Mineral di Kabupaten Indragiri Hilir, Tahun 2018

\begin{tabular}{llcc}
\hline No & \multicolumn{1}{c}{ Keterangan } & Lahan Gambut & Lahan Mineral \\
\hline 1 & Multiple R & 0,98 & 0,91 \\
2 & R Square & 0,96 & 0,83 \\
3 & Adjusted R Square & 0,95 & 0,78 \\
4 & Standard Error & 512,75 & 449,62 \\
5 & Observations & 25,00 & 19,00 \\
6 & F & 118,36 & 17,28 \\
\hline
\end{tabular}

kelapa belum optimal bila dilihat dari segi pendapatan petani, pemenuhan kebutuhan bahan baku industri dan sumber devisa negara secara nasional.

\section{Faktor-Faktor yang Mempengaruhi Produksi Kelapa Dalam pada Lahan Gambut dan Lahan Mineral di Kabupaten Indragiri Hilir}

Faktor produksi kelapa dalam diperoleh berdasarkan hasil regresi dari data primer (sampel petani kelapa) yang diolah dengan menggunakan perangkat lunak SPSS versi 11.5, maka akan diperoleh persamaan regresi berganda yang kemudian ditransformasikan ke dalam persamaan fungsi produksi CobbDouglas. Adapun yang menjadi variabel pada penelitian ini terdiri dari satu variabel terikat (dependent variable) dan empat variabel bebas (independent variable). Variabel yang dijadikan unit analisis regresi berganda ini yakni; Y: Produksi kelapa dalam; $\mathrm{X}_{1}$ : Lahan; $\mathrm{X}_{2}$ : Jumlah tanaman produktif; $\mathrm{X}_{3}$ : Tenaga kerja; $\mathrm{X}_{4}$ : Terusi. Dengan persamaan sebagai berikut:

Lahan Gambut:

$\mathrm{LnQ}=\mathrm{Ln} 192,98+2.821,98 \mathrm{LnX}_{1}+(8,33) \mathrm{LnX}_{2}+18$, $85 \mathrm{LnX}_{3}+(31,92) \mathrm{LnX}_{4}$

Lahan Mineral:

$\mathrm{LnQ}=\mathrm{Ln} 1.164,47+211,49 \operatorname{LnX}_{1}+2,50 \operatorname{LnX}_{2}+(50$, 30) $\mathrm{LnX}_{3}+137,78 \mathrm{LnX}_{4}$

Keterangan:

LnQ : Produksi kelapa dalam

$\operatorname{LnX}_{1} \quad:$ Lahan

$\mathrm{LnX}_{2} \quad:$ Jumlah tanaman produktif

$\mathrm{LnX}_{3} \quad:$ Tenaga kerja

$\mathrm{LnX}_{4} \quad:$ Terusi
Sehingga fungsi produksi dapat diperoleh sebagai berikut:

Lahan Gambut:

$\mathrm{LnQ}=192,98 \mathrm{X}_{1}{ }^{2.821,98} \mathrm{X}_{2}^{8,33} \mathrm{X}_{3}{ }^{18,85} \mathrm{X}_{4}{ }^{(31,92)}$

Lahan Mineral:

$\mathrm{LnQ}=1.164,47 \quad \mathrm{X}_{1}^{211,49} \quad \mathrm{X}_{2}^{2,50}$ $\mathrm{X}_{3}^{(50,30)} \mathrm{X}_{4}{ }^{137,78}$

\section{A. Uji Simultan (Uji F) Kelapa Dalam}

Pengaruh variabel bebas (Lahan; Jumlah tanaman produktif; Tenaga kerja; Terusi) secara serempak dapat dihitung dengan menggunakan uji F. Hasil pengujian dapat dilihat pada Tabel 3.

Berdasarkan Tabel 3 diperoleh nilai $F_{\text {hitung }}$ sebesar 118,38 pada lahan gambut dan 17,28 pada lahan mineral dengan tingkat kepercayaan $95 \%(\alpha=0,05)$. Disini bisa dilakukan pendekatan p-value atau sig., dimana sig. $<\alpha$, maka $\mathrm{H}_{0}$ ditolak dan $\mathrm{H}_{1}$ diterima artinya secara bersama-sama (serempak) variabel lahan; jumlah tanaman produktif; tenaga kerja dan terusi berpengaruh signifikan terhadap produksi kelapa dalam di kabupaten Indragiri Hilir. Dengan kata lain bahwa tanpa adanya input produksi akan mengakibatkan terhentinya proses produksi dan hasil produksi sama dengan nol.

\section{B. Uji Parsial (Uji T) Kelapa Dalam}

Hasil uji pengaruh variabel lahan; jumlah tanaman produktif; tenaga kerja dan terusi secara parsial dapat dilihat pada Tabel 4.

Berdasarkan Tabel 4, diperoleh informasi bahwa pada lahan gambut, variabel lahan $\left(\mathrm{X}_{1}\right)$ dan jumlah tanaman produktif $\left(\mathrm{X}_{2}\right)$ yang berpengaruh signifikan terhadap produksi kelapa. Sedangkan untuk lahan mineral, variabel terusi $\left(\mathrm{X}_{4}\right)$ berpengaruh terhadap 
Tabel 4. Uji T Kelapa Dalam Pada Lahan Gambut dan Lahan Mineral di Kabupaten Indragiri Hilir, Tahun 2018

\begin{tabular}{crrrrrrrr}
\hline Uraian & \multicolumn{3}{c}{ Lahan Gambut } & \multicolumn{3}{c}{ Lahan Mineral } \\
\cline { 2 - 9 } & Coefficients & $\begin{array}{c}\text { Standard } \\
\text { Error }\end{array}$ & t Stat & \multicolumn{1}{c}{$\begin{array}{c}\text { P- } \\
\text { value }\end{array}$} & Coefficients & $\begin{array}{c}\text { Standard } \\
\text { Error }\end{array}$ & t Stat & \multicolumn{1}{c}{$\begin{array}{c}\text { P- } \\
\text { value }\end{array}$} \\
\hline Intercept & 192,98 & 285,50 & 0,68 & 0,51 & $1.164,47$ & 307,75 & 3,78 & 0,00 \\
$\mathrm{X}_{1}$ & $2.821,98$ & 432,76 & 6,52 & 0,00 & 211,49 & 533,14 & 0,40 & 0,70 \\
$\mathrm{X}_{2}$ & $(8,33)$ & 2,99 & $(2,79)$ & 0,01 & 2,50 & 3,01 & 0,83 & 0,42 \\
$\mathrm{X}_{3}$ & 18,85 & 15,21 & 1,24 & 1,24 & $(50,30)$ & 27,19 & $(1,85)$ & 0,09 \\
$\mathrm{X}_{4}$ & $(31,92)$ & 51,47 & $(0,62)$ & 0,54 & 137,78 & 46,41 & 2,97 & 0,01 \\
\hline
\end{tabular}

produksi kelapa. Secara rinci dapat dilihat sebagai berikut:

\section{Lahan Gambut}

Pengaruh Lahan $\left(\mathbf{X}_{1}\right)$ Terhadap Produksi Kelapa Dalam

Dari Tabel 4, terlihat untuk variabel $\ln$ $\mathrm{X}_{1}$ (Lahan) diperoleh nilai $\mathrm{P}$-value 0.00 dengan tingkat kepercayaan $95 \%(\alpha=0,05)$, ini menunjukkan bahwa variabel lahan $\left(\mathrm{Ln} \mathrm{X}_{1}\right)$ berpengaruh terhadap produksi kelapa pada lahan gambut di kabupaten Indragiri Hilir. Variabel luas lahan berpengaruh terhadap produksi kelapa dikarenakan lahan yang dimiliki petani sampel umumnya memiliki lahan yang luas dengan rata-rata 2,24 ha. Luas lahan yang dimiliki petani mungkin saja sama namun populasi tanaman kelapa berbeda. Jarak tanam tiap petani kelapa berbeda, sehingga meskipun lahan sempit bisa ditanami pohon kelapa yang banyak. Dengan demikian, berpengaruh terhadap jumlah produksi per panen.

\section{Pengaruh Jumlah Tanaman Produktif $\left(\mathbf{X}_{2}\right)$ Terhadap Produksi Kelapa Dalam}

Berdasarkan Tabel 4, terlihat untuk variabel $\mathrm{X}_{2}$ (Jumlah Tanaman Produktif) diperoleh nilai $\mathrm{P}$-value sebesar 0,01 dengan tingkat kepercayaan $95 \%(\alpha=0,05)$. Maka dapat dikatakan variabel jumlah tanaman produktif $\left(\begin{array}{lll}\mathrm{Ln} & \mathrm{X}_{2}\end{array}\right)$ berpengaruh terhadap produksi kelapa dalam pada lahan gambut di kabupaten Indragiri Hilir. Variabel jumlah tanaman produktif berpengaruh terhadap produksi kelapa dikarenakan populasi kelapa menentukan produksi. Apabila dalam satu tandan menghasilkan buah kelapa 15-20 butir, maka dalam satu batang kelapa bisa berbuah 2-4 tandan kelapa. Jika dikalikan dengan jumlah tanaman yang menghasilkan, akan meningkatkan produksi kelapa.
2. Lahan Mineral

Pengaruh Terusi $\left(\mathbf{X}_{4}\right)$ Terhadap Produksi Kelapa Dalam

Dari Tabel 4, terlihat untuk variabel $\ln$ $\mathrm{X}_{4}$ (Terusi) diperoleh nilai $\mathrm{P}$-value sebesar 0,01 dengan tingkat kepercayaan 95\% $(\alpha=0,05)$. Maka dapat dikatakan variabel terusi $\left(\operatorname{Ln~} \mathrm{X}_{4}\right)$ berpengaruh terhadap produksi kelapa dalam pada lahan mineral di kabupaten Indragiri Hilir. Variabel terusi berpengaruh terhadap produksi kelapa dikarenakan sebagian petani kelapa menggunakan pupuk yang sesuai dengan kebutuhan tanaman kelapa. Apabila tanaman kelapa sudah mulai berkurang buahnya maka petani biasanya menggunakan terusi sebagai pemicu atau perangsang buah. Pada lahan mineral, pupuk pada tanaman kelapa harus diberikan karena tanah kelapa tercampur dengan air laut.

\section{KESIMPULAN}

Berdasarkan hasil penelitian di lapangan, maka dapat disimpulkan sebagai berikut:

1. Petani lahan gambut dan lahan mineral memiliki karektistik petani yang sama, umur petani produktif, tamat SD, jumlah tanggungan keluarga 3-4 orang dan pengalaman berusahatani 20-29 tahun.

2. Produksi lahan gambut lebih besar dibandingkan lahan mineral, begitu pula dengan pendapatan.

3. Faktor yang mempengaruhi produksi kelapa di lahan gambut adalah lahan dan jumlah tanaman produktif, sedangkan untuk lahan mineral yakni terusi.

\section{DAFTAR PUSTAKA}

Bavappa, K.V.A S.N. Darwis and D.D. Tarigans. 1995. Coconut Production and 
Productivity in Indonesia. Asian and Pacific Coconut Community 80pp.

Badan Pusat Statistik. 2016. Indragiri Hilir dalam Angka, Indragiri Hilir, Tembilahan

Direktorat Jenderal Perkebunan. 2017. Statistik Perkebunan Kelapa Indonesia. Jakarta.

Dongoran, F. R. 2013. Analisis Keuntungan Usaha Tani Kelapa di Kecamatan Padangsidimpuan Batunadua. Jurnal Tabularasa PPS Unimed, 10 (2); 151164.

Gujarati, D. 2001. Ekonometrika Dasar. Erlangga, Jakarta.

Heriyanto, H. and Darus, D., 2017. Analisis Efisiensi Faktor Produksi Karet di Kabupaten Kampar Provinsi Riau. Dinamika Pertanian, 33(2), pp.1-10

Heriyanto, H., Asrol, A., Karya, D. and Ningsih, V.Y., 2018. Analisis Faktor Produksi Kalapa Sawit Rakyat Menurut Tipologi Lahan di Kabupaten Indragiri Hilir Provinsi Riau. Jurnal Lahan Suboptimal, 7(1).

Lamunsa, A. 2005. Faktor-Faktor yang Mempengaruhi Produksi Kelapa Dalam di Desa Labuan Lele Kecamatan Tawaeli Kabupaten Donggala. Jurnal Agroland, 12(3): 254-260.

Palungkun, R. 2001. Aneka Produk Olahan Kelapa, Cetakan ke Sembilan. Penebar Swadaya, Jakarta.

Pangkey, M.C., Vecky, A.J. Masinambow., Albert T. Londa. 2016. Perbandingan Tingkat Pendapatan Petani Kelapa di Kabupaten Minahasa Selatan (Studi Kasus di Desa Ongkaw I dan Desa Tiniawangko Kecamatan Sinonsayang). Jurnal Berkala Ilmiah Efisiensi, 16(02): 233-242.
Rahim dan Diah, 2008. Pengantar, Teori dan Kasus Ekonometrika Pertanian. Penebar Swadaya, Jakarta.

Ruauw, E., Jenny, B., Devison P. 2011. Kajian Pengelolaan Usahatani Kelapa di Desa Tolombukan Kecamatan Pasan Kabupaten Minahasa Tenggara. ASE, 7(2): 39-50.

Soekartawi. 2003. Teori ekonomi Produksi dengan Pokok Bahasan Analisis Fungsi Cobb Douglass. CV Rajawali, Jakarta.

Supadi dan Nurmanaf AR. 2006. Pemberdayaan Petani Kelapa Dalam Upaya Peningkatan Pendapatan. Jurnal Litbang Pertanian. Hal 26.

Tarigans, D.D. 2005. Diversifikasi Usahatani Kelapa sebagai Upaya untuk Meningkatkan Pendapatan Petani. Perspektif, 4(2): 71-78.

Vaulina,S. Khairizal dan Hajry. 2017. Efisiensi Usahatani Kelapa Dalam (Cocos nucifera Linn) di Kecamatan Gaung Anak Serka Kabupaten Indragiri Hilir Propinsi Riau. Laporan Penelitian Dosen Pemula Hibah Dikti.

Widarjono, A. 2007. Ekonometrika: Teori dan Aplikasi untuk Ekonomi dan Bisnis Edisi Kedua. Ekonisia Fakultas Ekonomi UII, Yogyakarta. 